\title{
APAKAH KEPUTUSAN PEMBELIAN KONSUMEN JAVA ORIGIN TERKAIT DENGAN PEMASARAN PRODUK ONLINE?
}

\author{
Liem Evan Wiryono \\ Program Studi International Business Management \\ Fakultas Manajemen Bisnis Universitas Ciputra Surabaya \\ Citraland CBD Boulevard Surabaya 60219 Indonesia \\ evanwiryono@gmail.com \\ Liliana Dewi \\ Program Studi International Business Management \\ Fakultas Manajemen Bisnis Universitas Ciputra Surabaya \\ Citraland CBD Boulevard Surabaya 60219 Indonesia \\ Ldewi@ciputra.ac.id (*corresponding author)
}

\begin{abstract}
Java Origin is a company that produces batik shirts in modern design by using mixing cloth and denim fabric. This study aims to determine the influence of online media and personal selling of people in this research to know the purchasing decisions of Java Origin consumers. Determination of source data used samples saturated with 77 respondents, that is consumers who have purchased Java Origin products. The method in this research is a quantitative method. This data retrieval method uses a questionnaire that is distributed directly by using multiple linear regression as a data analysis technique. The result of this research is the online media and personal sale variable influence significant to a decision of purchasing Java Origin.
\end{abstract}

Keywords: online media, personal selling, decision of purchasing.

\begin{abstract}
ABSTRAK
Java Origin adalah perusahaan yang memproduksi kemeja batik dalam desain modern dengan menggunakan kain pencampur dan kain denim. Penelitian ini bertujuan untuk mengetahui pengaruh media online dan penjualan pribadi terhadap orang-orang dalam penelitian ini untuk mengetahui keputusan pembelian konsumen Java Origin. Penentuan sumber data menggunakan sampel jenuh dengan 77 responden, yaitu konsumen yang telah membeli produk Java Origin. Metode dalam penelitian ini adalah metode kuantitatif. Metode pengambilan data ini menggunakan kuesioner yang didistribusikan secara langsung dengan menggunakan regresi linier berganda sebagai teknik analisis data. Hasil dari penelitian ini adalah variabel media online dan penjualan pribadi berpengaruh signifikan terhadap keputusan pembelian Java Origin.
\end{abstract}


Kata Kunci: media online, personal selling, keputusan pembelian.

\section{PENDAHULUAN}

Teknologi informasi saat ini merupakan kebutuhan yang harus dimiliki oleh setiap organisasi untuk dapat meningkatkan kualitas layanannya. Penggunaan teknologi informasi seperti internet sudah menjadi semakin dibutuhkan oleh setiap orang di dunia. Ini didukung oleh akses ke dunia internet yang semakin mudah dan cepat, sehingga memudahkan orang untuk melakukan pekerjaannya dan mencari informasi, karena rata-rata smartphone sekarang dilengkapi aksesnya (Siswanto, 2018).

Media sosial seperti Instagram mempercepat pengusaha dalam memasarkan produknya dengan cepat dan efisien, karena dengan kehadiran media sosial pengusaha dapat mengurangi biaya operasionalnya untuk memasarkan produk. Hanya dengan mengunggah katalog produk yang dijual dan rajin melakukan promosi secara rutin, produk yang dijual akan lebih mudah dikenal masyarakat luas. Pengguna internet di seluruh dunia telah mencapai 31,7 miliar dan dari tahun ke tahun jumlah pengguna internet telah meningkat sebesar 7,6 persen, sedangkan pengguna media sosial sendiri mencapai 2,2 miliar dengan pengguna seluler mencapai 3,7 miliar. Menurut Kementerian Komunikasi dan Informasi Republik Indonesia, 80 persen pengguna internet di Indonesia terdiri dari remaja berusia 1519 tahun, sedangkan pada kenyataannya, remaja menggunakan internet tidak hanya untuk kebutuhan pendidikan, tetapi juga untuk hiburan, belanja, media sosial, dan sebagainya (Sherlyanita dan Rakhmawati, 2016).

Media sosial menjadi semakin populer sebagai bisnis dan komunikasi. Pelaku bisnis menyadari bahwa media sosial sangat penting untuk berkomunikasi secara pribadi dan dapat menerapkan strategi pemasaran yang tepat dan dapat meningkatkan citra merek yang digunakan. Berdasarkan fakta-fakta ini, dapat disimpulkan bahwa strategi pemasaran menggunakan e-commerce seperti situs web dan media sosial sangat potensial untuk pengembangan perusahaan (Lavoie, 2015).

Batik saat ini tidak hanya dikenakan pada sejumlah acara resmi, tetapi dapat dikenakan pula dalam acara apa pun, seperti ketika pergi ke kantor, pergi keluar, pergi ke pesta, atau hanya bersantai di rumah. Semakin maraknya batik saat ini, ternyata juga berdampak pada tren mode di Indonesia. Kini semakin sering terlihat anak muda yang mulai mengenakan batik baik untuk acara formal maupun hanya untuk pakaian santai. Ini tidak lepas dari campur tangan para pengrajin batik dan desainer pakaian yang membuat batik terlihat lebih modern dan tidak meninggalkan nilai budaya batik itu sendiri, sehingga dapat diterima oleh anak muda. Inovasi dalam hal motif, warna, hingga model baju batik adalah salah satu trik pasti untuk menyelaraskan batik dengan zaman. Berkat ide dan sentuhan artistik dari perancang dan pengrajin batik, pakaian batik lahir dengan tampilan yang lebih indah, eksklusif, elegan, dan dinamis (Lutfiati, 2017).

Sebagai anak bangsa, para pemuda harus melestarikan budaya bangsa yang benar-benar indah, termasuk pakaian batik. Java Origin memproduksi kaos batik 
yang didesain modern menggunakan campuran seperti katun dan denim untuk membuat penampilan kaos batik Java Origin dijual sebagai pakaian batik modern dan dapat diterima oleh semua orang, terutama anak muda yang biasanya tidak suka memakai batik, karena mereka terkesan kuno atau terlihat seperti orang tua. Java Origin sedang berusaha mengubah citra batik menjadi mode yang bisa disukai oleh anak muda. Mayoritas penjualan Java Origin adalah melalui sistem bisnis ke pelanggan.

Business to customer (B2C) adalah kegiatan e-bisnis yang dilakukan langsung oleh perusahaan untuk konsumen atau perorangan, di mana kegiatan transaksi umumnya menggunakan mekanisme toko online seperti Instagram, situs web, dan jalur yang berisi katalog produk yang ditawarkan (Himawan et al., 2015).

Transaksi penjualan langsung di internet dan pesanan dapat langsung dilakukan oleh konsumen karena informasi tentang detail produk sudah terdaftar di halaman katalog produk Java Origin. Selain mengandalkan media sosial untuk promosi produk media, Java Origin berpartisipasi dalam pameran dari berbagai penyelenggara, mengikuti bazar yang biasanya diadakan di mal dan bazaar tertentu yang dimiliki oleh Universitas Ciputra. Kegiatan yang dilakukan oleh Java Origin sejak awal perusahaan didirikan dengan tujuan untuk meningkatkan penjualan, dan meningkatkan citra merek Java Origin dalam rangka mencapai target penjualan sebesar Rp. 4.000.000,- setiap semester. Penjualan Java Origin sering kehilangan target yang ditentukan.

Ada beberapa dimensi media online yang perlu dipertimbangkan oleh bisnis, yaitu: relevansi pribadi, interaktivitas, pesan, dan keakraban merek (Nurgayatri, 2016). Dalam penelitian ini, keakraban merek masih belum digunakan karena merek Java Origin belum banyak dikenal. Penelitian ini bertujuan untuk mengetahui pengaruh media online dan personal selling terhadap keputusan pembelian konsumen Java Origin.

\section{TINJAUAN PUSTAKA}

Seiring perkembangannya, internet mampu melahirkan jaringan baru yang biasa dikenal dengan media sosial. Media online adalah media yang memudahkan orang untuk berpartisipasi, berbagi, dan membuat konten termasuk blog, jejaring sosial, wi-fi, forum, dan dunia virtual. Awalnya media online hanya digunakan sebagai alat komunikasi untuk terhubung dengan teman, rekan kerja, dan keluarga. Namun dalam perkembangannya, media online tidak hanya digunakan sejauh itu. Media sosial sekarang banyak digunakan untuk menyebarkan dan memberikan berbagai informasi, mulai dari informasi politik, bisnis, pendidikan, kuliner, kesehatan, budaya, hiburan, hingga kegiatan promosi produk (Rahman dan Panuju, 2017).

Promosi dengan dukungan selebritas memiliki pengaruh individu positif dan signifikan terhadap minat beli konsumen dalam bisnis toko online pakaian wanita di Denpasar. Promosi dengan dukungan selebritas memiliki pengaruh positif dan signifikan terhadap kepercayaan merek pada bisnis toko online pakaian wanita di Denpasar. Kepercayaan merek berpengaruh positif dan signifikan terhadap minat beli konsumen dalam bisnis toko online pakaian wanita di Denpasar (Jodi dan Adhika, 2019). 
Ada pengaruh yang signifikan dari penjualan pribadi dan promosi penjualan pada keputusan konsumen untuk menyelamatkan Britama di PT Bank Rakyat Indonesia (Persero) Tbk. (Diansari dan Budiadi, 2016). Personal selling adalah interaksi tatap muka dengan satu atau lebih calon pembeli untuk tujuan membuat presentasi, menjawab pertanyaan, dan mendapatkan pesanan. Tahapan proses penjualan pribadi adalah prospecting dan kualifikasi, pra-pendekatan, pendekatan, presentasi, demonstrasi, penanganan keberatan, penutupan, dan tindak lanjut (Wahyuni dan Widaningsih, 2017).

Penelitian menunjukkan TF Miracle Water memperhatikan dan mempertimbangkan dari mulut ke mulut, kualitas layanan, kualitas produk, dan promosi lebih komprehensif untuk menentukan strategi pemasaran untuk membangun keputusan pembelian konsumen (Asmayaty, 2017).

Citra merek secara simultan, harga, dan kualitas produk secara signifikan mempengaruhi keputusan pembelian ponsel Xiaomi di Kota Langsa (Amalia dan Nst, 2017). Indikator keputusan pembelian: kebutuhan dan keinginan suatu produk, keinginan untuk mencoba, stabilitas kualitas suatu produk, keputusan pembelian (Dewi, 2017).

\section{METODE PENELITIAN}

Penelitian ini menggunakan metode kuantitatif dengan populasi dan sampel dari konsumen yang telah membeli produk Java Origin. Hasil akhir dari penelitian ini diambil dari wawancara singkat untuk memfasilitasi pemahaman dan simpulan. Populasi adalah area generalisasi yang terdiri dari objek/subjek yang memiliki jumlah, dan karakteristik tertentu yang ditentukan oleh peneliti untuk dipelajari dan kemudian ditarik simpulan (Sugiyono, 2014).

Pada penelitian ini, peneliti mengambil data dari 77 responden yang membeli batik Java Origin pada 2015-2017 dan berusia 18-50 tahun. Metode pengumpulan data ini menggunakan kuesioner yang didistribusikan secara langsung. Teknik pengambilan sampel menggunakan metode sampling jenuh yang merupakan teknik penentuan sampel jika semua anggota populasi digunakan sebagai sampel (Sugiyono, 2014).

Metode pengumpulan data untuk penelitian ini adalah dengan menggunakan kuesioner yang akan dibagikan langsung kepada responden yang telah ditentukan yaitu pelanggan yang telah membeli produk Java Origin. Jenis data yang akan digunakan peneliti dalam penelitian ini adalah data primer. Data primer akan diambil dengan menggunakan metode kuesioner yang didistribusikan ke sampel yang dimaksudkan oleh para peneliti. Jenis kuesioner yang digunakan dalam penelitian ini adalah kuesioner tertutup. Metode pengumpulan data menggunakan kuesioner menggunakan skala Likert. Skala Likert bertujuan untuk mengukur sikap, pendapat, dan persepsi seseorang atau sekelompok orang tentang suatu fenomena (Sugiyono, 2014).

\section{MODEL ANALISIS}

Model yang dipakai untuk melakukan analisis seperti terlihat pada Gambar 1 di bawah ini. 


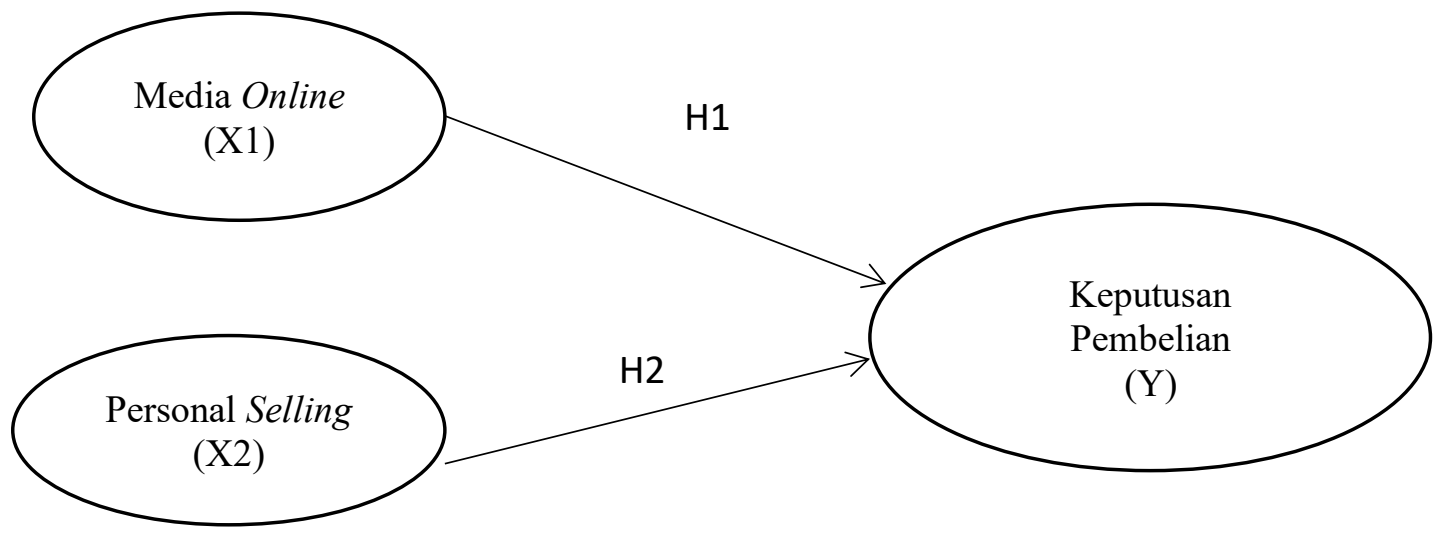

Gambar 1

Model Analisis

\section{HASIL PENELITIAN}

\section{Pengaruh Media Online pada Keputusan Pembelian}

Manfaat media sosial memiliki hubungan positif dengan keputusan pembelian pelanggan. Pada penelitian ini, media online memiliki pengaruh signifikan terhadap keputusan pembelian (Song and Yoo, 2016). Hal ini dapat dilihat dari hasil persamaan analisis regresi berganda dan hasil perhitungan regresi linier. Pada Tabel 1 dapat dilihat bahwa variabel media online (X1) memiliki efek positif 0,488 atau $48,8 \%$ dari keputusan pembelian (Y). Nilai hasil uji t yang telah dilakukan yaitu nilai Sig. dari uji t lebih kecil dari 0,05 dan nilai signifikansi variabel media online adalah 0,000 . Hasil di atas menunjukkan bahwa variabel media online (X1) memiliki pengaruh signifikan dan parsial pada variabel keputusan pembelian (Y). Berdasarkan hasil yang diperoleh dari responden yang telah mengisi kuesioner ini, ditemukan bahwa responden paling banyak berusia 2122 tahun. Dapat dikatakan bahwa mayoritas pelanggan Java Origin adalah remaja. Setelah penelitian ini, Java Origin harus meningkatkan konten yang tersedia di media online, sehingga konsumen dapat mengetahui informasi terbaru tentang produk Java Origin. Selain itu, Java Origin harus menyediakan lebih banyak media online, sehingga konsumen dapat lebih mudah menjangkau contact person yang disediakan oleh Java Origin dan yang terakhir masih mempertahankan kinerja yang baik dan mencoba untuk menyempurnakannya lagi.

Tabel 1

Hasil Analisis Linear Berganda

\begin{tabular}{|l|l|c|c|}
\hline \multicolumn{5}{|c|}{ Coefficient } \\
\hline & \multicolumn{1}{|c|}{ Unstandardized Coefficient } & $\mathrm{t}$ & Sig. \\
\hline Model & \multicolumn{1}{|c|}{ B } & & \\
\hline (Constant) & 0,769 & 2,810 & 0,008 \\
\hline Media Online $\left(\mathrm{X}_{1}\right)$ & 0,488 & 4,916 & 0,000 \\
\hline Personal Selling $\left(\mathrm{X}_{2}\right)$ & 0,277 & 2,205 & 0,034 \\
\hline \multicolumn{2}{|l|}{ Dependent variable: Keputusan Pembelian $(\mathrm{Y})$} \\
\hline
\end{tabular}


Berdasarkan data pada Tabel 1, hasil perhitungan persamaan regresi linier berganda dalam penelitian ini adalah:

$\mathrm{Y}=0,769+0,488 \mathrm{X} 1+0,277 \mathrm{X} 2$

di mana:

X1: Media Online

X2: Personal Selling

Y: Keputusan Pembelian

\section{PEMBAHASAN}

\section{Pengaruh Personal Selling terhadap Keputusan Pembelian}

Personal selling adalah interaksi tatap muka dengan satu atau lebih calon pembeli untuk tujuan membuat presentasi, menjawab pertanyaan, dan mendapatkan pesanan. Semakin sering bisnis mahasiswa Universitas Ciputra melakukan kegiatan personal selling, kesadaran merek terhadap bisnis baik produk maupun layanan juga meningkat. Meningkatkan kesadaran merek, konsumen akan lebih percaya diri untuk membeli produk (Wahyuni dan Widaningsih, 2017).

Hasil penelitian yang mengungkapkan bahwa ada hubungan positif dengan kesadaran merek juga mengungkapkan hal yang sama bahwa personal selling memiliki hubungan positif dan kuat dengan keputusan pembelian (Dewi, 2017). Pada penelitian ini, penjualan pribadi memiliki pengaruh signifikan terhadap keputusan pembelian. Hal ini dapat dilihat dari hasil persamaan analisis regresi berganda dan hasil perhitungan regresi linier. Pada Tabel 1 dapat dilihat bahwa variabel personal selling (X1) memiliki pengaruh positif sebesar 0,277 atau 27,7\% terhadap keputusan pembelian (Y). Nilai hasil uji t yang telah dilakukan yaitu nilai Sig. dari uji t lebih kecil dari 0,05 dan nilai signifikansi variabel personal selling adalah 0,034. Hasil ini menunjukkan bahwa variabel personal selling (X2) memiliki pengaruh signifikan dan parsial terhadap variabel keputusan pembelian (Y). Berdasarkan hasil yang diperoleh dari responden yang telah mengisi kuesioner ini, ditemukan bahwa responden paling banyak berusia 21-22 tahun. Ini bisa dikatakan kebanyakan pelanggan berusia 21-22 tahun. Mayoritas konsumen yang telah membeli produk-produk Java Origin mengatakan produk-produk yang disediakan oleh Java Origin sesuai dengan kebutuhan konsumen. Adanya peraturan Universitas Ciputra untuk mengenakan batik setiap hari Rabu juga mempengaruhi konsumen untuk membeli batik. Namun, pendekatan awal kepada konsumen kurang mampu membujuk minat konsumen untuk mengetahui lebih lanjut tentang produk yang dijual, selain layanan yang tidak memuaskan juga merupakan salah satu faktor yang mempengaruhi keputusan pembelian pada produk Java Origin. Oleh karena itu, perlu untuk lebih memperhatikan strategi dalam membujuk konsumen dan meningkatkan layanan kepada konsumen, sehingga konsumen tertarik untuk membeli produk Java Origin. 


\section{SIMPULAN}

Variabel media online dalam penelitian ini berpengaruh positif signifikan terhadap keputusan pembelian produk Java Origin. Semakin banyak konten yang terdaftar di media online, semakin tinggi keputusan pembelian konsumen. Variabel personal selling dalam penelitian ini memiliki pengaruh positif signifikan terhadap keputusan pembelian untuk produk Java Origin. Semakin baik persuasi konsumen dan layanan yang lebih baik kepada konsumen menyebabkan semakin tinggi keputusan pembelian dari konsumen.

\section{SARAN}

Dari hasil penelitian tentang pengaruh media online pada keputusan pembelian Java Origin, maka diharapkan di masa depan lebih banyak perusahaan akan meningkatkan konten yang terkandung dalam media online perusahaan. Hal ini bertujuan untuk lebih memperkenalkan produk-produk Java Origin ke komunitas yang lebih luas, sehingga konsumen potensial dapat melihat konten yang tersedia dan tertarik untuk membeli produk. Berdasar hasil penelitian tentang pengaruh personal selling terhadap keputusan pembelian Java Origin, diharapkan perusahaan dapat meningkatkan strategi pemasaran, sehingga dapat menarik perhatian konsumen untuk mengetahui lebih banyak produk dan membuat keputusan pembelian. Selain itu perusahaan diharapkan dapat meningkatkan kualitas layanan kepada konsumen.

\section{DAFTAR PUSTAKA}

Amalia, S. dan M. O. A. Nst, 2017, Pengaruh Citra Merek, Harga, dan Kualitas Produk terhadap Keputusan Pembelian Handphone Merek Xiaomi di Kota Langsa, Jurnal Manajemen dan Keuangan.

Asmayaty, I., 2017, Pengaruh Word Of Mouth, Kualitas Layanan, Kualitas Produk, dan Promosi Terhadap Keputusan Pembelian Konsumen (Studi Kasus Tf Miracle Water). JMM UNRAM - Master Of Management Journal, https://doi.org/10.29303/jmm.v6i3.160.

Dewi, L., 2017, Integrated Marketing Communication Terhadap Brand Awareness Pada Bisnis Mahasiswa Universitas Ciputra 2013 (p. 7).

Diansari, A. A. R. dan S. Budiadi, 2016, Pengaruh Personal Selling dan Sales Promotion Terhadap Keputusan Konsumen Manabung Britama di PT. Bank Rakyat Indonesia (Persero), Tbk Cabang Sidoarjo, Jurnal Universitas Negeri Surabaya.

Himawan, H., A. Saefullah, dan S. Santoso, 2015, Analisa dan Perancangan Sistem Informasi Penjualan Online (E-Commerce) pada CV Selaras Batik Menggunakan Analisis Deskriptif, Scientific Journal of Informatics, https://doi.org/10.15294/sji.v1i1.3641.

Jodi, I Wayan Gede Antok Setiawan dan I Nyoman Reza Adhika, 2019, Pengaruh Promosi Dengan Celebrity Endorse Terhadap Brand Trust, dan Minat Beli 
Konsumen pada Bidang Usaha Online Shop Pakaian Perempuan di Denpasar (Study pada Dinda Fashion Bali), JMM UNRAM - Master Of Management Journal, https://doi.org/10.29303/jmm.v8i1.358.

Lavoie, K., 2015, Instagram and Branding: A Case Study of Dunkin' Donuts, Elon Journal of Undergraduate Research in Communications.

Lutfiati, D., 2017, Minat Konsumen Terhadap Batik Mirota Surabaya, Jurnal Penelitian Busana, dan Desain (JPBD).

Nurgayatri, A. R., 2016, Pengaruh Promosi Online Pada Media Sosial Terhadap Keputusan Online Promotion Effect on Social Media Consumer Buying Decisions Brand Elmeira, Fakultas Ekonomi, dan Bisnis, Universitas Telkom.

Rahman, I. A. dan R. Panuju, 2017, Strategi Komunikasi Pemasaran Produk Fair $N$ Pink Melalui Media Sosial Instagram, Wacana, Jurnal Ilmiah Ilmu Komunikasi, https://doi.org/10.32509/wacana.v16i2.26.

Sherlyanita, A. K. dan N. A. Rakhmawati, 2016, Pengaruh, dan Pola Aktivitas Penggunaan Internet serta Media Sosial pada Siswa SMPN 52 Surabaya, Journal of Information Systems Engineering and Business Intelligence, https://doi.org/10.20473/jisebi.2.1.17-22.

Siswanto, T., 2018, Optimalisasi Sosial Media Sebagai Media Pemasaran Usaha Kecil Menengah, Liquidity, https://doi.org/10.32546/lq.v2i1.134.

Song, S. and M. Yoo, 2016, The role of social media during the pre-purchasing stage, Journal of Hospitality and Tourism Technology, https://doi.org/10. 1108/JHTT-11-2014-0067.

Sugiyono, 2014, Metode Penelitian Pendidikan Pendekatan Kuantitatif.pdf in Metode Penelitian Pendidikan Pendekatan Kuantitatif, Kualitatif, dan R\&D.

Wahyuni, R. F. dan S. Widaningsih, 2017, Pengaruh Promosi Personal Selling, dan Direct Marketing Terhadap Keputusan Pembelian di Astra Credit Companies (ACC) Bandung, E-Proceeding of Applied Science, 3 (3), page $1122-1128$. 